American Journal of Pharmacology and Toxicology 7 (2): 68-72, 2012

ISSN 1557-4962

(C) 2012 Science Publications

\title{
Quercetin in Dimethyl Benzanthracene Induced Breast Cancer in Rats
}

\author{
${ }^{1}$ Natla Sashidhar Reddy, ${ }^{2}$ Parthasarathy Nirmala, \\ ${ }^{3}$ Natesan Chidambaram and ${ }^{4}$ Pammi Ashok Kumar \\ ${ }^{1}$ Division of Pharmacology, \\ ${ }^{2}$ Division of Pharmacology, \\ ${ }^{3}$ Division of Medicine, \\ ${ }^{4}$ Division of Biochemistry, \\ Rajah Muthiah Medical college, Annamalai University, \\ Annamalai Nagar, Chidambaram, Tamilnadu, India
}

\begin{abstract}
Problem statement: Vincristine a commonly used anticancer agent in the treatment of breast cancer results in serious adverse effects like teratogenicity, neurotoxicity and carcinogenicity on long term use. Drug resistance is also a common problem encountered with vincristine. Hence the effect of flavonol quercetin, a known antioxidant with no known documented adverse effect was tried in treatment of DMBA induced breast cancer in female rats and its effect was compared with vincristine. Approach: Quercetin at the dose of 50, 100-200 mg kg${ }^{-1}$ body weight was administered in DMBA induced breast cancer in female wistar rats and its effects were compared with Vincristine. The anti oxidant enzymes, catalase, glutathione peroxidase and superoxide dismutase and Thiobarbituric Acid Reactive Substances (TBARS) level in cancerous breast tissue, TBARS and catalase in plasma and superoxide dismutase and glutathione peroxidase in erythrocyte lysate were estimated. Results: Quercetin supplementation at the dose of $100 \mathrm{mg} \mathrm{kg}^{-1}$ body weight was most effective in alleviating cancer symptoms and was comparable to vincristine. The plasma TBARS were reduced and breast tissue TBARS were elevated. The antioxidant enzymes were rejuvenated by quercetin supplementation at all three dose levels. Conclusion: Quercetin is found to be an effective chemotherapeutic agent in the treatment of breast cancer on par with vincristine. Being a plant product, quercetin can also be used in chemoprophylaxis in high risk individuals with genetic predisposition towards breast cancer. Besides, it can be given orally and has a wide margin of safety.
\end{abstract}

Key words: Vincristine, Thiobarbituric Acid Reactive Substances (TBARS), quercetin supplementation, breast cancer, antioxidant enzymes, glutathione peroxidase

\section{INTRODUCTION}

Breast cancer is the leading cause of morbidity and mortality in women. Worldwide, it is the second most common type of cancer. The incidence of breast cancer is highest in developed North American and North European countries and lowest in South America and Asia (Althuis et al., 2005). The higher incidence is attributed to delayed first child birth, shorter duration of breast feeding, family history of breast cancer, early menarche and late menopause. Westernization of lifestyle, changes in dietary habits, indiscriminate exposure to exogenous estrogen is often considered to be reasons for the higher incidence reported in developing countries. Breast cancer originates from breast tissue most commonly from inner lining of milk ducts or lobules that supply the ducts with milk
(Sariego, 2010). The primary route of metastasis is the lymphatic system or blood stream.

Quercetin is a major flavonol distributed ubiquitously in edible plants and is one of the most potent antioxidants of plant origin (Erdman et al., 2007). The daily intake of quercetin in western diet is estimated to range between 0 to $30 \mathrm{mg}$ with a median of $10 \mathrm{mg}$ (Egert et al., 2008). It is abundantly found in Allium cepa (onion), Solanum lycopersicum (tomato), Vitis vinifera (grape), Olea europa (olive), Morus alba (white mulberry), Thea sinesis (tea) and Crataegus cuneata (thorn apple). Quercetin is claimed to have antioxidant (Filipe et al., 2004), anti allergic (Marozzi et al., 1970), anti atherogenic (Janisch et al., 2004), anti-inflammatory (Wadsworth and Koop, 1999) and antiangiogenic (Chan et al., 2000) actions.

Breast cancer can be induced by 7, 12-Dimethyl Benzanthracene (DMBA), a site specific pro-

Corresponding Author: Natla Sashidhar Reddy, Division of Pharmacology, Rajah Muthiah Medical College,

Annamalai University, Annamalai Nagar, Chidambaram, Tamilnadu, India Tel: 00919500370047 
Am. J. Pharm. \& Toxicol., 7 (2): 68-72, 2012

carcinogen with selectivity for breast cancer in experimental rats. It undergoes metabolic activation to become the ultimate carcinogen dihydrodiol peroxide (Miyata et al., 2001). The carcinogenic and mutagenic activities of DMBA require metabolic activation by mixed function oxidizes located in rat liver microsomes (Yang and Dower, 1975). The dihydrodiol epoxide binds with adenine residues of DNA resulting in mutagenesis and carcinogenesis (Garcia-Segura et al., 1992).

The aim of the present study is to evaluate the effect of quercetin on thiobarbituric acid reactive substances, antioxidant enzymes like superoxide dismutase, glutathione peroxidase and catalase in breast tissue, thiobarbituric acid reactive substances and catalase in plasma and superoxide dismutase and glutathione peroxidase in erythrocyte lysate and to compare its efficacy with vincristine, a well known anticancer agent used in the treatment of breast cancer.

\section{MATERIALS AND METHODS}

Chemicals and carcinogen: 7, 12-Dimethyl Benzanthracene (DMBA) was purchased from Sigma chemical company (St. Louis MO, USA) and quercetin from Allergic research group, USA. All other chemicals and reagents used were of analytical grade.

Preparation of the drug: Quercetin powder was used as suspension in $0.1 \%$ carboxymethyl cellulose and each rat received a daily dose of 50,100 and $200 \mathrm{mg}$ $\mathrm{kg}^{-1}$ body weight of quercetin in $2 \mathrm{~mL}$ of suspension. 7 , 12-dimethyl benzanthracene was dissolved in an emulsion of sunflower oil $(0.75 \mathrm{~mL})$ and physiological saline $(0.25 \mathrm{ml})$ just prior to use.

Animals and Experimental design: 36 female wistar rats $(\mathrm{n}=6$ per group) $6-8$ weeks old, weighing $150 \mathrm{~g}$ ms were used in the study (Table 1). 7, 12-dimethyl benzanthracene was given at the dose of $7.5 \mathrm{mg} \mathrm{kg}^{-1}$ subcutaneously in the mammary region once a week for four consecutive weeks. Vincristine was given in the dose of $500 \mu \mathrm{g} \mathrm{kg}^{-1}$ intraperitoneally every week for four consecutive weeks.

The study was started after getting approval from the Institutional Animal Ethical Committee (IAEC). The rats were housed in the animal house, Rajah Muthiah Medical College, Annamalai University in an air conditioned room with a $12 \mathrm{~h}$ light and dark cycle. The animals were provided with vitamin enriched pellet diet consisting of $23 \%$ Wheat flour, $60 \%$ roasted Bengal gram powder, 5\% skimmed milk powder, $4 \%$ casein, $4 \%$ refined oil, salt mixture with $4 \%$ starch and choline. The rats were maintained in accordance with the Indian National Law on animal care and use (Reg No 190/2007/CPCSEA).
Table 1: Experimental Design

\begin{tabular}{|c|c|c|}
\hline $\begin{array}{l}\text { Group } 1 \\
\mathrm{n}=6\end{array}$ & Control & $\begin{array}{l}\text { Rats received pellet diet for } \\
16 \text { weeks and served as control }\end{array}$ \\
\hline $\begin{array}{l}\text { Group } 2 \\
\mathrm{n}=6\end{array}$ & $\begin{array}{l}\text { 7, 12-dimethyl } \\
\text { benzanthracene }\end{array}$ & $\begin{array}{l}\text { Rats received pellet diet for } \\
16 \text { weeks and were administered } \\
7,12 \text {-dimethyl benzanthracene } \\
\left(7.5 \mathrm{mg} \mathrm{kg}^{-1}\right) \text { subcutaneously once } \\
\text { a week for } 4 \text { weeks. }\end{array}$ \\
\hline $\begin{array}{l}\text { Group } 3 \\
n=6\end{array}$ & Vincristine & $\begin{array}{l}\text { Rats received pellet diet for } \\
16 \text { weeks and were administered } \\
7,12 \text {-dimethyl benzanthracene } \\
\left(7.5 \mathrm{mg} \mathrm{kg}^{-1}\right) \text { subcutaneously and } \\
\text { Vincristine } 500 \mu \mathrm{g} / \mathrm{kg} \text { intraperitoneally } \\
\text { once a week for } 4 \text { weeks. }\end{array}$ \\
\hline $\begin{array}{l}\text { Group } 4 \\
n=6\end{array}$ & $\begin{array}{l}\text { Quercetin } \\
50 \mathrm{mg}\end{array}$ & $\begin{array}{l}\text { Rats received pellet diet along with } \\
\text { quercetin } 50 \text { mg through oral gavages for } \\
16 \text { weeks and were administered } 7,12 \\
\text {-dimethyl benzanthracene }\left(7.5 \mathrm{mg} \mathrm{kg}^{-1}\right) \\
\text { subcutaneously once a week for } 4 \text { weeks. }\end{array}$ \\
\hline $\begin{array}{l}\text { Group } 5 \\
n=6\end{array}$ & $\begin{array}{l}\text { Quercetin } \\
100 \mathrm{mg}\end{array}$ & $\begin{array}{l}\text { Rats received pellet diet along with quercetin } \\
100 \mathrm{mg} \text { through oral gavage for } 16 \text { weeks and } \\
\text { were administered } 7,12 \text {-dimethyl } \\
\text { benzanthracene }\left(7.5 \mathrm{mg} \mathrm{kg}^{-1}\right) \text { subcutaneously } \\
\text { once a week for } 4 \text { weeks }\end{array}$ \\
\hline $\begin{array}{l}\text { Group } 6 \\
n=6\end{array}$ & $\begin{array}{l}\text { Quercetin } \\
200 \mathrm{mg}\end{array}$ & $\begin{array}{l}\text { Rats received pellet diet along with quercetin } \\
200 \mathrm{mg} \text { through oral gavage for } 16 \text { weeks and } \\
\text { were administered } 7,12 \text {-dimethyl } \\
\text { benzanthracene }\left(7.5 \mathrm{mg} \mathrm{kg}^{-1}\right) \text { subcutaneously } \\
\text { once a week for } 4 \text { weeks }\end{array}$ \\
\hline
\end{tabular}

Experimental design: The total period of study was 16 weeks (Table 1). The weight of the rats was recorded at the beginning of the experiment at weekly intervals and at the end of the study period. The animals were sacrificed after overnight fasting at the end of 16 weeks.

Blood collection and preparation of erythrocyte lysate: After sacrificing the rats, blood was collected into $5.0 \mathrm{ml}$ heparinized tubes and plasma was separated by centrifugation at $800 \times \mathrm{g}$ for $5 \mathrm{~min}$ at $4^{\circ} \mathrm{C}$. After separation of plasma, the buffy coat was removed and packed cells were washed thrice with ice cold physiological saline containing glucose $(5.5 \mathrm{mM})$.

Erythrocyte lysate was prepared by lysing a known volume of erythrocytes by addition of two volumes of distilled water to packed erythrocytes and were centrifuged at $3000 \times \mathrm{g}$ for $10 \mathrm{~min}$ at $4^{\circ} \mathrm{C}$ to separate the erythrocyte lysate.

Mammalian erythrocytes have a limited life span and greater sensitivity to oxidative damage. The presence of high concentration of iron in erythrocytes makes it vulnerable to oxidative damage (Glass and Gershon, 1984). Reactive Oxygen Species (ROS) interacts with ferric ion to form ferrous ion which generates a very highly reactive hydroxyl ion that is critical in causing molecular damage (Masotti et al., 1988).

Preparation of tissue homogenate: The breast tissue was excised immediately after animal was sacrificed and washed with chilled isotonic saline. 
Am. J. Pharm. \& Toxicol., 7 (2): 68-72, 2012

The tissue homogenate was prepared in ice cold $0.1 \mathrm{M}$ Tris-HCL buffer at $\mathrm{pH}$ 7.2. The homogenate was centrifuged and the supernatant was used for assays.

Estimation of antioxidant enzyme activity and Thiobarbituric Acid Reactive Subtances (TBARS) in tissues and plasma were determined by the method of Ohkawa et al. (1979). The level of superoxide dismutase was estimated by the method of Kakkar et al. (1984). Catalase was assayed through the method of Sinha (1972). The level of glutathione peroxidase was determined by the method of Rotruck et al. (1973). The results were compared with vincristine group.

Statistical analysis: The statistical significance of the data was determined using one way Analysis of Variance (ANOVA) and the significant difference between the treatments groups were evaluated by Duncan's Multiple Range Test (DMRT). The results were considered as statistically significant at $p<0.05$.

\section{RESULTS}

General observations: There was no statistically significant difference in the final body weight (g) body weight gain loss $(\mathrm{g})$, food intake $\left(\mathrm{g}^{-1}\right)$ and food efficiency (body weight gain $\left(\mathrm{g}^{-1}\right)$ food intake) among the experimental groups (data not shown).

Effect on lipid peroxidation product: Plasma thiobarbituric acid reactive substances (Table 2) were significantly elevated $(<0.05)$ while breast thiobarbituric acid reactive substances were significantly reduced $(<0.05)$ in the DMBA treated group. Quercetin supplementation at all three dose levels 50, 100 and $200 \mathrm{mg} \mathrm{kg}^{-1}$ (groups 4, 5, 6) along with DMBA altered these levels. The plasma thiobarbituric acid reactive substances were reduced and breast thiobarbituric acid reactive substances were elevated significantly in the quercetin treated group. The difference in the level of thiobarbituric acid reactive substances was more evident with the supplementation of $100 \mathrm{mg} \mathrm{kg}^{-1}$ of quercetin (group 5) and was comparable to vincristine group (group 3 ).

Effect on antioxidant enzymes superoxide dismutase, catalase and glutathione peroxidase The levels of erythrocyte lysate and breast superoxide dismutase (Table 3) and glutathione peroxidase (Table 4) were significantly reduced in DMBA treated group.
Table 2: Effect of quercetin and DBMA on Thiobarbituric Acid Reactive Substances (TBARS) level in control and experimental groups

\begin{tabular}{|c|c|c|}
\hline Groups & $\begin{array}{l}\text { Plasma TBARS } \\
\text { (nmoles/ml plasma) }\end{array}$ & $\begin{array}{l}\text { Breast TBARS } \\
\text { (mmoles/mg tissue) }\end{array}$ \\
\hline Group 1 control & $1.97 \pm 0.18^{\mathrm{a}}$ & $0.25 \pm 0.02^{\mathrm{a}}$ \\
\hline Group 2 DMBA* & $6.70 \pm 0.58^{\mathrm{b}}$ & $0.08 \pm 0.01^{\mathrm{b}}$ \\
\hline $\begin{array}{l}\text { Group } 3 \text { DMBA+ Vincristine } \\
\left(500 \mu \mathrm{kg}^{-1} \text {.b.wt) }\right.\end{array}$ & $2.22 \pm 0.22^{\mathrm{c}}$ & $0.27 \pm 0.07^{\mathrm{c}}$ \\
\hline $\begin{array}{l}\text { Group } 4 \text { DMBA + Quercetin } \\
\text { (50 } \mathrm{mg} \mathrm{kg}^{-1} \text { b.wt.) } \\
\text { Group } 5 \text { DMBA + Quercetin }\end{array}$ & $2.83 \pm 0.23^{\mathrm{d}}$ & $0.29 \pm 0.03^{\mathrm{d}}$ \\
\hline $\begin{array}{l}\text { Group } 5 \text { DMBA + Quercetın } \\
\text { (100mg kg-1 b.wt.) } \\
\text { Group } 6 \text { DMBA + Quercetin }\end{array}$ & $2.16 \pm 0.41^{\mathrm{a}, \mathrm{c}}$ & $0.27 \pm 0.03^{\mathrm{c}}$ \\
\hline $\begin{array}{l}\text { Group } 6 \text { DMBA + Quercetin } \\
\left(200 \mathrm{mg} \mathrm{kg}^{-1} \text { b.wt.) }\right.\end{array}$ & $2.98 \pm 0.26^{\mathrm{d}}$ & $0.28 \pm 0.03^{\mathrm{d}}$ \\
\hline
\end{tabular}

All the values are expressed as mean \pm S.D. of 6 rats in each group. Values that have a different superscript letter $(a, b, c, d)$ differ significantly with each other $(\mathrm{p}<0.05, \mathrm{DMRT})$ * : 7, 12-dimethyl benzanthracene

Table 3:Effect of quercetin and DBMA on Superoxide Dismutase (SOD) activity in control and experimental groups

\begin{tabular}{|c|c|c|}
\hline Groups & $\begin{array}{l}\text { Erythrocyte lysate } \\
\text { SOD (U/mg Hb) }\end{array}$ & $\begin{array}{l}\text { Breast SOD } \\
\text { (U/mg protein) }\end{array}$ \\
\hline Group 1 Control & $3.23 \pm 0.28^{\mathrm{a}}$ & $6.87 \pm 0.60^{\mathrm{a}}$ \\
\hline Group 2 DMBA* & $2.10 \pm 0.19^{\mathrm{b}}$ & $3.12 \pm 0.30^{\mathrm{b}}$ \\
\hline $\begin{array}{l}\text { Group } 3 \text { DMBA+ Vincristine } \\
\left(500 \mu \mathrm{g} \mathrm{kg}^{-1} \text {.b.wt) }\right.\end{array}$ & $3.53 \pm 0.32^{\mathrm{c}}$ & $6.98 \pm 0.62^{\mathrm{a}}$ \\
\hline $\begin{array}{l}\text { Group } 4 \text { DMBA + Quercetin } \\
\text { (50 } \mathrm{mg} \mathrm{kg}^{-1} \text { b.wt.) }\end{array}$ & $3.12 \pm 0.30^{\mathrm{d}}$ & $6.63 \pm 0.63^{\mathrm{c}}$ \\
\hline $\begin{array}{l}\text { Group } 5 \text { DMBA + Quercetin } \\
\text { (100 } \mathrm{mg} \mathrm{kg}^{-1} \text { b.wt.) }\end{array}$ & $3.38 \pm 0.42^{\mathrm{c}, \mathrm{e}}$ & $7.73 \pm 0.78^{\mathrm{a}, \mathrm{d}}$ \\
\hline $\begin{array}{l}\text { Group } 6 \text { DMBA + Quercetin } \\
\text { (200 } \mathrm{mg} \mathrm{kg}^{-1} \text { b.wt.) }\end{array}$ & $2.70 \pm 0.31^{\mathrm{f}}$ & $6.85 \pm 0.74^{\mathrm{a}}$ \\
\hline
\end{tabular}

All the values are expressed as mean \pm S.D. of 6 rats in each group. Values that have a different superscript letter (a,b,c,d) differ significantly with each other $(\mathrm{p}<0.05$, DMRT). * 7,12 dimethyl benzanthracene

Table 4: Effect of quercetin and DBMA on Glutathione Peroxidase (GPx) activity in control and experimental groups

\begin{tabular}{|c|c|c|}
\hline Groups & $\begin{array}{l}\text { ( } \mu \text { moles of GSH } \\
\text { utilized/min/mg Hb) } \\
\text { Erythrocyte lysate GPx }\end{array}$ & $\begin{array}{l}\text { ( } \mu \text { moles of GSH } \\
\text { utilized/min/mg } \\
\text { protein)breast GPx }\end{array}$ \\
\hline Group 1 Control & $28.40 \pm 2.01^{\mathrm{a}}$ & $6.90 \pm 0.66^{\mathrm{a}}$ \\
\hline Group 2 DMBA* & $15.90 \pm 1.12^{\mathrm{b}}$ & $3.90 \pm 0.37^{\mathrm{b}}$ \\
\hline $\begin{array}{l}\text { Group } 3 \text { DMBA+ Vincristine } \\
\left(500 \mu \mathrm{kg}^{-1} \text {.b.wt) }\right.\end{array}$ & $28.89 \pm 2.46^{\mathrm{a}}$ & $6.33 \pm 0.62^{\mathrm{a}}$ \\
\hline $\begin{array}{l}\text { Group } 4 \text { DMBA + Quercetin } \\
\text { (50mg kg-1 b.wt.) } \\
\text { Group } 5 \text { DMBA + Quercetin }\end{array}$ & $21.58 \pm 2.64^{\mathrm{C}}$ & $5.63 \pm 0.43^{\mathrm{c}}$ \\
\hline $\begin{array}{l}\text { (100mg kg }{ }^{-1} \text { b.wt.) } \\
\text { Group } 6 \text { DMBA + Quercetin }\end{array}$ & $27.31 \pm 2.85^{\mathrm{a}, \mathrm{d}}$ & $6.73 \pm 0.58^{\mathrm{a}}$ \\
\hline (200 $\mathrm{mg} \mathrm{kg}^{-1}$ b.wt.) & $23.81 \pm 3.02^{\mathrm{c}}$ & $5.86 \pm 0.55^{\mathrm{c}}$ \\
\hline
\end{tabular}

All the values are expressed as mean \pm S.D. of 6 rats in each group. Values that have a different superscript letter (a, b, c, d) differ significantly with each other $(\mathrm{p}<0.05$, DMRT). * 7,12 dimethyl benzanthracene

Similarly the levels of plasma and breast catalase (Table 5) was reduced significantly in DMBA treated group when compared to control, vincristine and quercetin treated groups indicating the oxidative damage induced by DMBA. Quercetin supplementation at the dose of 50-200 mg kg-1 (group 4, 6) rejuvenated these antioxidant enzymes and quercetin at the dose of $100 \mathrm{mg} \mathrm{kg}^{-1}$ (group 5) further increased their levels. 
Am. J. Pharm. \& Toxicol., 7 (2): 68-72, 2012

Table 5:Effect of quercetin and DBMA on Catalase (CAT) level in control and experimental groups

\begin{tabular}{|c|c|c|}
\hline Groups & $\begin{array}{l}\text { Plasma CAT } \\
\left(\mu \text { moles of } \mathrm{H}_{2} \mathrm{O}_{2}\right. \\
\text { utilized } / \mathrm{min} / \mathrm{mg} \mathrm{Hb})\end{array}$ & $\begin{array}{l}\text { Breast CAT } \\
\text { ( } \mu \text { moles of } \mathrm{H}_{2} \mathrm{O}_{2} \\
\text { utilized/min } / \mathrm{mg} \text { protein) }\end{array}$ \\
\hline Group 1 Control & $2.60 \pm 0.23^{\mathrm{a}}$ & $64.50 \pm 4.22^{\mathrm{a}}$ \\
\hline Group 2 DMBA* & $1.50 \pm 0.13^{\mathrm{b}}$ & $35.80 \pm 3.42^{\mathrm{b}}$ \\
\hline $\begin{array}{l}\text { Group } 3 \mathrm{DMBA}^{-1} \text { Vincristine } \\
\left(500 \mu \mathrm{kg}^{-1} \text {.b.wt) }\right.\end{array}$ & $2.85 \pm 0.27^{\mathrm{a}}$ & $63.52 \pm 6.34^{\mathrm{a}}$ \\
\hline $\begin{array}{l}\text { Group } 4 \text { DMBA + Quercetin } \\
\text { (50mg kg }{ }^{-1} \text { b.wt.) }\end{array}$ & $3.04 \pm 0.33^{\mathrm{c}}$ & $60.25 \pm 6.13^{\mathrm{c}}$ \\
\hline $\begin{array}{l}\text { Group } 5 \mathrm{DMBA}^{-} \text {Quercetin } \\
\text { (100mg kg-1 b.wt.) } \\
\text { Group } 6 \text { DMBA + Quercetin }\end{array}$ & $3.34 \pm 0.58^{\mathrm{d}}$ & $63.46 \pm 6.09^{\mathrm{a}}$ \\
\hline (200 $\mathrm{mg} \mathrm{kg}^{-1}$ b.wt.) & $2.22 \pm 0.29^{\mathrm{e}}$ & $58.17 \pm 5.87^{\mathrm{d}}$ \\
\hline $\begin{array}{l}\text { All the values are expr } \\
\text { group. Values that have } \\
\text { differ significantly with }\end{array}$ & ed as me & $\begin{array}{l}\text { of } 6 \text { rats in each } \\
\text { letter }(a, b, c, d) \\
\text { DMRT). } * 7,12-\end{array}$ \\
\hline
\end{tabular}

\section{DISCUSSION}

Superoxide anion, the main reactive oxygen species is potentially toxic and can be mutagenic or carcinogenic (Nordberg and Arner, 2001). Superoxide dismutase, superoxide and hydrogen peroxide affects the basic biology of cells and tissues (Buettner, 2011). Generation of free radicals in vivo will affect cellular proliferation and invasion. Although a cell can tolerate the toxic effects of small amounts of free radicals, extensive cellular damage can be the result of enormous free radical production (Nakagami et al., 1999). The inverse relationship between lipid peroxidation and the rate of cellular proliferation, seen in our study indicates that the tumor cells proliferate extensively when lipid peroxidation is minimal. The thiobarbituric acid reactive substances in plasma were significantly increased whereas its level in breast tissue was significantly reduced in DMBA treated rats. The tumor cells in breast tissue showed a distinctly low level of peroxidation creating a favorable atmosphere for the proliferation of cancer cells (Schmelz et al., 2000). Quercetin supplementation significantly altered the lipid peroxidation status. The most significant effect of quercetin supplementation was seen at the dose of $100 \mathrm{mg} \mathrm{kg}^{-1}$ body weight and was comparable to vincristine group.

The antioxidant enzymes superoxide dismutase, catalase and glutathione peroxidase play a key role in the cellular defense against free radical damage (Sun, 1990). Superoxide dismutase is necessary for scavenging superoxide anions formed during the early stages of oxidative damage. Quercetin rejuvenated the levels of the key antioxidant enzyme superoxide dismutase in erythrocyte lysate and in plasma of experimental rats treated with DMBA. The action of quercetin $100 \mathrm{mg} \mathrm{kg}^{-1}$ (group 5) was greater than the action of vincristine in breast tissue and was comparable to the action of vincristine in plasma. Superoxide dismutase, being the primary antioxidant enzyme plays a greater role in the protection of cells against the oxidative damage induced by DMBA. By elevating both erythrocyte lysate and breast superoxide dismutase to near normal values, quercetin can be considered as an effective agent in the prevention of cancer. Catalase catalyses the formation of water and oxygen from hydrogen peroxide and has a rapid turnover rate. Catalase decreases the chromosomal aberrations and delays the onset of neoplastic transformation in mouse fibroblasts epidermal keratinocytes (Jones et al., 1985). DMBA decreases the level of catalase in both plasma and breast tissue when compared to control. Quercetin at all three dose levels increased the levels of plasma and breast catalase. The action of quercetin $100 \mathrm{mg}$ was greater than the action of vincristine.

Glutathione is needed for the stability of erythrocytes. Oxidation of glutathione leads to hemolysis. The level of glutathione peroxidase of DMBA treated rats in erythrocyte lysate and breast tissuewere low when compared with the control group. Quercetin at $100 \mathrm{mg} \mathrm{kg}^{-1}$ resulted in almost $100 \%$ replenishment of breast glutathione peroxidase level and increased the levels of erythrocyte lysate glutathione peroxidase level on par with vincristine group.

Vincristine, a semisynthetic analogue of the plant Catharanthus roseus is an antimitotic anticancer agent used extensively in leukemia, neuroblastoma, Wilms tumor, carcinoma of breast, lung, ovary, cervix, colon, hodgkins, non-hodgkins lymphoma and in many other types of cancer. It acts by stimulating microtubule depolymerization and mitotic spindle destruction. Vincristine also increases apoptosis by increasing the concentrations of cellular tumor antigen p53-p21 and by inhibiting Bcl-2 activity. Drug resistance is a common problem encounterd with vincristine in cancer chemotherapy. It is given intravenously and long term use may be associated with the risk of carcinogenicity. As a known teratogenic agent, it can cause gonadal suppression, neurotoxicity, alopecia and other side effects.

Quercetin, a bioflavonoid and plant product has the following advantages over vincristine. It can be given orally and has wide margin of safety. No serious adverse effects have been reported so far. It has been reported to inhibit the p-glycoprotein mediated drug efflux and can overcome the drug resistant.

\section{CONCLUSION}

The capacity of flavonols to act as antioxidant in cells definitely represents a fascinating potential in the field of oncology. Our study also reveals that quercetin can be a potential chemo preventive agent in breast cancer. It is most effective at the dose of $100 \mathrm{mg} \mathrm{kg}^{-1}$ body weight. Quercetin at $100 \mathrm{mg} \mathrm{kg}^{-1}$ was either comparable or superior to the action of vincristine. It can be given prophylactically in high risk groups with a genetic preponderance towards breast cancer. 


\section{REFERENCES}

Althuis, MD., JM. Dozier, WF. Anderson, SS. Devesa and LA. Brinton, 2005. Global trends in breast cancer incidence and mortality 1973-1997. Int. J. Epidemiol., 34: 405-412. PMID: 15737977

Buettner, G.R., 2011. Superoxide dismutase in redox biology: the roles of superoxide and hydrogen peroxide. Anticancer Agents Med Chem., 11: 341346. PMID: 21453242

Chan, M.M., J.A. Mattiacci, H.S. Hwang, A. Shah and D. Fong, 2000. Synergy between ethanol and grape polyphenols, quercetin, and resveratrol, in the inhibition of the inducible nitric oxide synthase pathway. Biochem. Pharmacol., 60: 1539-1548. PMID: 11020457

Egert, S., S. Wolfren, A.B. Westphal, A.E. Wagner and J. Frank et al., 2008. Daily quercetin supplementation dose-dependently increases plasma quercetin concentrations in healthy humans. J. Nutr., 138: 1615-1621. PMID: 18716159

Erdman, J.W. Jr, D. Balentine, L. Arab, G. Beecher and J.T. Dwyer et al., 2007. Flavonoids and heart health. J. Nutr., 137: 718-737. PMID: 17311968

Filipe, P., J. Haigle, J.N. Silva, J. Freitas and A. Fernandes et al., 2004. Anti- and pro-oxidant effects of quercetin in copper-induced low density lipoprotein oxidation. Quercetin as an effective antioxidant against pro-oxidant effects of urate. Eur. J. Biochem., 271: 1991-1999. PMID: 15128308

Garcia-Segura, L.M., F. Bojda-Diolez, V. Lenoir, F. Naftrolin and B. Kerdelhue, 1992. Estrogen-like effects of the mammary carcinogen 7,12dimethylbenz(alpha)anthracene on hypothalamic neuronal membranes. Brain. Res. Bull., 28: 625628. PMID: 1617445

Glass, G.A. and D. Gershon, 1984. Decreased enzymic protection and increased sensitivity to oxidative damage in erythrocytes as a function of cell and donor aging. Biochem. J., 218: 531-37. PMID: 6712629

Janisch, K.M., G. Williamson, P. Needs and G.W. Plumb, 2004. Properties of quercetin conjugates: Modulation of LDL oxidation and binding to human serum albumin. Free Radic. Res., 38: 877884. PMID: 15493462

Jones, G.M., K.K. Sanford, R. Parshad, R. Gannt and F.M. Price et al., 1985. Influence of added catalase on chromosome stability and neoplastic transformation of mouse cells in culture. Br. J. Cancer, 52: 583-590. PMID: 2415146

Kakkar, P., B. Das, P.N. Viswanathan, 1984. A modified spectrophotometric assay of superoxide dismutase. Ind. J. Biochem. Biophys., 21: 130132. PMID: 6490072
Masotti, L., E. Casali and T. Galeotti, 1988. Lipid peroxidation in tumour cells. Free Radic. Biol. Med., 4: 377-386. PMID: 3290063

Marozzi, F., J. Jr, A.B. Kocialski and M.H. Malone, 1970. Studies on the antihistaminic effects of thymoquinone, thymohydroquinone and quercetin. Arzneimittelforschung, 20: 1574-77. PMID: 4394727

Miyata, M., M. Furukawa, K. Takahashi, F.J. Gonzalez and Y. Yamazoe et al., 2001. Mechanism of 7, 12dimethylbenzanthracene induced immunotoxicity: Role of Metabolic activation at the Target Organ. Jap. J. Pharmacol., 86: 302-309. PMID: 11488430

Nakagami, K., T. Uchida, S. Ohwada, Y. Koibuchi and Y. Morishita, 1999. Increased choline kinase activity in 1,2 dimethylhydrazine induced rat colon cancer. Jpn. J. Cancer Res., 90: 1212-1217. PMID: 10622531

Nordberg, J. and E.S.J. Arner, 2001. Reactive oxygen species, antioxidants and mammalian thioreduxin system. Free Radic. Biol. Med., 31: 1287-1312. PMID: 11728801

Ohkawa, H., N. Onishi and K. Yagi, 1979. Assay for lipid peroxides in animal tissue by thiobarbituric acid reaction. Anal. Biochem., 95: 351-358. PMID: 36810

Rotruck, J.T., A.L. Pope, H.E. Ganther, A.B. Swanson and D.G. Hafeman et al., 1973. Selenium: Biochemical role as a component of glutathione peroxidase. Science, 179: 588-590. PMID: 4686466

Sariego, J., 2010. Breast cancer in the young patient. Am. Sur., 76: 1397-1401. PMID: 21265355

Schmelz, E.M., M.C. Sullards, D.L. Dillehay and A.H. Merill Jr, 2000. Colonic cell proliferation and aberrant crypt foci formation are inhibited by dairy glycosphingolipids in 1, 2-dimethylhydrazinetreated CF1 mice. J. Nutr., 130: 522-527. PMID: 10702579

Sinha, A.K., 1972. Colorimetric assay of catalase. Analytical Biochem., 47: 389-394. PMID: 4556490

Sun, Y., 1990. Free radicals, antioxidant enzymes and carcinogenesis. Free Radic. Biol. Med., 8: 583-599. PMID: 2193855

Wadsworth, T.L. and D.R. Koop, 1999. Effects of the wine polyphenolics quercetin and resveratrol on pro-inflammatory cytokine expression in RAW 264.7 macrophages. Biochem. Pharmacol., 57: 941-49. PMID: 10086329

Yang, S.K. and W.V. Dower, 1975. Metabolic pathways of 7,12-dimethylbenz[a]anthracene in hepatic microsomes. Proc. Nat. Acad. Sci. USA. 72: 2601-2605. PMID: 809767 